Article

\title{
Two New Daucane Sesquiterpenoids from Daphne aurantiaca
}

\author{
You-Xing Zhao ${ }^{\dagger} *$, Sheng-Zhuo Huang ${ }^{\dagger}$, Qing-Yun Ma, Wen-Li Mei and Hao-Fu Dai * \\ Institute of Tropical Bioscience and Biotechnology, Chinese Academy of Tropical Agricultural Sciences, \\ Haikou 571101, Hainan, China; E-Mails: huangshengzhuo@yahoo.com.cn (S.-Z.H.); \\ maqy1024@163.com (Q.-Y.M.); meiwenli@yahoo.com.cn (W.-L.M.) \\ $\dagger$ These authors contributed equally to this work. \\ * Authors to whom correspondence should be addressed; E-Mails: zhaoyx1011@163.com (Y.-X.Z.); \\ hfdai@126.com (H.-F.D.); Tel./Fax: +86-898-6698-9095 (Y.-X.Z.).
}

Received: 2 July 2012; in revised form: 16 August 2012 / Accepted: 17 August 2012 /

Published: 24 August 2012

\begin{abstract}
Two new daucane sesquiterpenoids 1 $\beta, 2 \beta$-epoxy-10(H) $\alpha$-dauca-11(12)-ene-

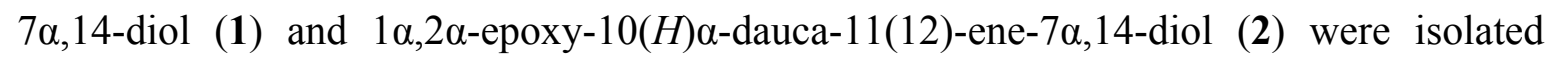
from the plateau medicinal plant Daphne aurantiaca Diels. (Thymelaeceae). Their structures were elucidated by 1D and 2D NMR spectroscopy, as well as HR-ESI-MS data.
\end{abstract}

Keywords: Daphne aurantiaca; Thymelaeceae; daucane

\section{Introduction}

Daphne aurantiaca Diels. (Thymelaeceae) is an evergreen shrub widely distributed in the plateau area of southwest China and used traditionally in folk medicine [1]. The bark is used for the treatment of tranumatic injury [2]. The Thymelaeceae plants were claimed to provide good medicines against tumors [3], inflammation [2], antihyperglycemic [4], and neurotrophic [5]. Recently, some phenols and daphane diterpenoids from Daphne acutiloba have showed strong anti-HIV-1 activities [6,7]. Previous studies have also reported a series of sesquiterpenoids and diterpenoids isolated from $D$. aurantiaca with potential anti-inflammatory activities [2]. In order to study new bioactive constituents from this plant, the phytochemical investigation have been carried out, and two new dacane sesquiterpenoids named $1 \beta, 2 \beta$-epoxy-10(H) $\alpha$-dauca-11(12)-ene-7 $\alpha, 14$-diol (1) and $1 \alpha, 2 \alpha$-epoxy-10(H)- $\alpha$-dauca-11(12)- 
ene-7 $\alpha, 14$-diol (2) were isolated. Herein, we describe the isolation, structural elucidation of the new compounds as well as their anti-HIV-1 and acetylcholinesterase (AChE) inhibitory activities.

\section{Results and Discussion}

Compound 1 was obtained as a yellow oil, and its molecular formula was assigned as $\mathrm{C}_{15} \mathrm{H}_{24} \mathrm{O}_{3}$ by HR-ESI-MS ( $m / z$ 275.1628 $[\mathrm{M}+\mathrm{Na}]^{+}$calcd. for $\mathrm{C}_{15} \mathrm{H}_{24} \mathrm{O}_{3} \mathrm{Na}$ 275.1623) and NMR data (Table 1), indicating four degrees of unsaturation.

Table 1. NMR data of compounds 1 and 2 in $\mathrm{CDCl}_{3}\left({ }^{1} \mathrm{H}: 500 \mathrm{MHz} ;{ }^{13} \mathrm{C}: 125 \mathrm{MHz} ; \delta\right.$ in ppm, $J$ in $\mathrm{Hz}$ ).

\begin{tabular}{cllll}
\hline \multirow{2}{*}{ Position } & \multicolumn{1}{c}{$\mathbf{1}$} & \multicolumn{2}{c}{$\mathbf{2}$} & $\boldsymbol{\delta}_{\mathbf{C}}$ \\
\cline { 2 - 5 } & $\boldsymbol{\delta}_{\mathbf{H}}$ & $\boldsymbol{\delta}_{\mathbf{C}}$ & $\boldsymbol{\delta}_{\mathbf{H}}$ & 67.5 \\
$\mathbf{1}$ & - & 67.5 & - & 61.8 \\
$\mathbf{2}$ & $3.27(1 \mathrm{H}, \mathrm{dd}, 6.8,7.7)$ & 59.4 & $3.15(\mathrm{dd}, 1 \mathrm{H}, 1.6,4.8)$ & 26.8 \\
$\mathbf{3}$ & $2.16(1 \mathrm{H}, \mathrm{ddd}, 3.1,7.7,14.2)$ & 27.0 & $2.15(\mathrm{ddd}, 1 \mathrm{H}, 3.1,4.8,15.6)$ & \\
& $1.53(1 \mathrm{H}, \mathrm{ddd}, 6.8,13.3,14.2)$ & & $1.53(\mathrm{ddd}, 1 \mathrm{H}, 1.6,13.3,15.6)$ & \\
$\mathbf{4}$ & $1.88(1 \mathrm{H}, \mathrm{m})$ & 48.3 & $2.25(\mathrm{ddd}, 1 \mathrm{H}, 3.1,13.3,13.5)$ & 46.1 \\
$\mathbf{5}$ & - & 43.3 & - & 41.8 \\
$\mathbf{6}$ & $1.85(1 \mathrm{H}, \mathrm{dd}, 12.6,16.3)$ & 50.1 & $1.87(1 \mathrm{H}, \mathrm{dd}, 5.0,16.3)$ & 48.4 \\
& $1.66(1 \mathrm{H}, \mathrm{dd}, 1.6,16.3)$ & & $1.46(1 \mathrm{H}, \mathrm{dd}, 11.6,16.3)$ & \\
$\mathbf{7}$ & $3.85(1 \mathrm{H}, \mathrm{dd}, 1.6,12.6)$ & 72.6 & $4.29(1 \mathrm{H}, \mathrm{dd}, 5.0,11.6)$ & 68.2 \\
$\mathbf{8}$ & $1.61(1 \mathrm{H}, \mathrm{m})$ & 42.9 & $1.47(1 \mathrm{H}, \mathrm{m})$ & 43.3 \\
& $1.41(1 \mathrm{H}, \mathrm{m})$ & & $1.40(1 \mathrm{H}, \mathrm{m})$ & \\
$\mathbf{9}$ & $1.92(1 \mathrm{H}, \mathrm{m})$ & 29.9 & $1.85(1 \mathrm{H}, \mathrm{m})$ & \\
& $1.77(1 \mathrm{H}, \mathrm{m})$ & & $1.76(1 \mathrm{H}, \mathrm{m})$ & \\
$\mathbf{1 0}$ & $2.95(1 \mathrm{H}, \mathrm{ddd}, 2.2,13.5,13.6)$ & 50.0 & $2.92(1 \mathrm{H}, \mathrm{ddd}, 2.2,13.4,14.3)$ & 50.7 \\
$\mathbf{1 1}$ & - & 149.0 & - & 148.3 \\
$\mathbf{1 2}$ & $4.79(1 \mathrm{H}, \mathrm{d}, 1.3)$ & 113.4 & $4.85(1 \mathrm{H}, \mathrm{d}, 1.3)$ & \\
& $4.68(1 \mathrm{H}, \mathrm{d}, 1.3)$ & & $4.74(1 \mathrm{H}, \mathrm{d}, 1.3)$ & 23.4 \\
$\mathbf{1 3}$ & $1.66(3 \mathrm{H}, \mathrm{s})$ & 23.2 & $1.73(3 \mathrm{H}, \mathrm{s})$ & 61.8 \\
$\mathbf{1 4}$ & $3.90(1 \mathrm{H}, \mathrm{d}, 12.9)$ & 60.6 & $4.07(1 \mathrm{H}, \mathrm{d}, 12.5)$ & 18.3 \\
\hline & $3.75(1 \mathrm{H}, \mathrm{d}, 12.9)$ & & $3.30(1 \mathrm{H}, \mathrm{d}, 12.5)$ & \\
$\mathbf{1 5}$ & $0.99(3 \mathrm{H}, \mathrm{s})$ & 18.3 & $0.85(3 \mathrm{H}, \mathrm{s})$ & \\
\hline
\end{tabular}

The IR spectrum displayed the presence of hydroxyls $\left(3,425 \mathrm{~cm}^{-1}\right)$ and olefinic bond $\left(1,635 \mathrm{~cm}^{-1}\right)$ absorptions. Analysis of its ${ }^{13} \mathrm{C}-\mathrm{NMR}$ and DEPT spectra (Table 1) showed the presence of 15 carbon resonances. These carbons were assigned to two singlet methyl groups, six methylenes (including one oxygenated and one terminal double bond), four methines (including two oxygenated), and three quaternary carbons (including one oxygenated). Comparing the ${ }^{13} \mathrm{C}-\mathrm{NMR}$ data (Table 1) of $\mathbf{1}$ with those of dauca-1,11-diene-7 $\alpha, 14$-diol [2] showed that $\mathbf{1}$ had the same daucane skeleton. The differences were that the C-1 $\left(\delta_{\mathrm{C}}\right.$ 127.4) and C-2 $\left(\delta_{\mathrm{C}}\right.$ 143.8) in dauca-1,11-diene-7 $\alpha, 14$-diol shifted up-field to $\delta_{\mathrm{C}} 67.5$ and 59.4 in compound 1, respectively, corresponding to $\mathrm{H}-2\left[\delta_{\mathrm{H}} 5.78(1 \mathrm{H}\right.$, d, $J=5.6 \mathrm{~Hz})]$ in dauca-1,11-diene-7 $\alpha, 14$-diol shifted up-field to $\delta_{\mathrm{H}} 3.27(1 \mathrm{H}$, dd, $J=6.8,7.7 \mathrm{~Hz})$ in $\mathbf{1}$, which suggested that compound 1 was generated from dauca-1,11-diene-7 $\alpha, 14$-diol with C-1-C-2 
double bond oxidized to a epoxy group, combined with the analysis of its molecular formula. The key HMBC correlations (Figure 1) of 1 from H-2 $\left[\delta_{\mathrm{H}} 3.27(1 \mathrm{H}, \mathrm{dd}, J=6.8,7.7 \mathrm{~Hz})\right], \mathrm{H}-7\left[\delta_{\mathrm{H}} 3.85(1 \mathrm{H}, \mathrm{d}\right.$, $J=1.5,12.6 \mathrm{~Hz})]$, and $\mathrm{H}-14$ to $\mathrm{C}-1\left[\delta_{\mathrm{C}} 67.5(\mathrm{~s})\right]$ further clarified this hypothesis.

Figure 1. Key 2D NMR correlations of compounds 1 and 2.
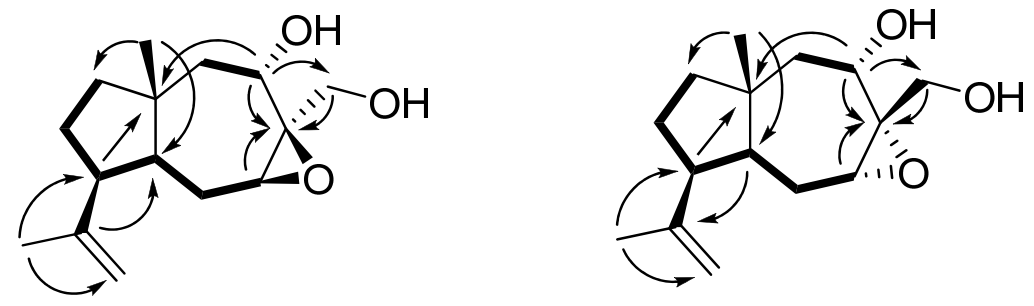

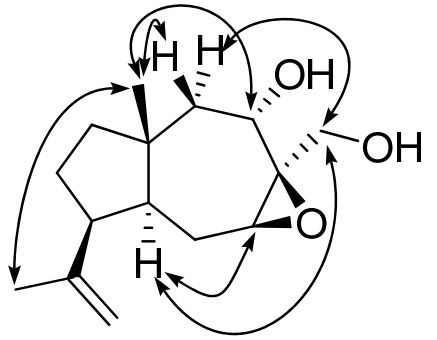

1

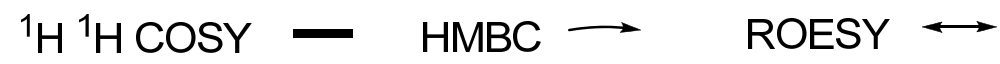

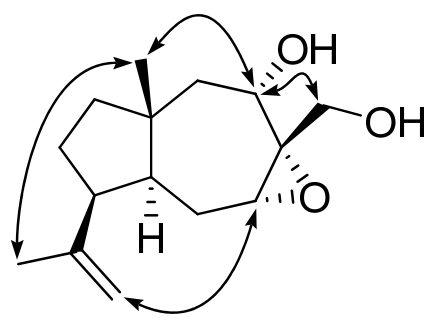

2

The other correlations in the HMBC and ${ }^{1} \mathrm{H}-{ }^{1} \mathrm{H}$ COSY (Figure 1) spectrum further confirmed the atom connectivity in $\mathbf{1}$. The relative configurations of the stereogenic centers (C-4, C-5, and C-7) of 1 were elucidated by comparison of NMR data with dauca-1,11-diene-7 $\alpha, 14$-diol and NOESY spectrum (Figure 1) and determined to be the same as those of dauca-1,11-diene-7 $\alpha, 14$-diol with $\beta$-orientations of $\mathrm{CH}_{3}-15$ and $\mathrm{H}-7$ and $\alpha$-orientation of $\mathrm{H}-4$. The $\beta$-orientation of the epoxy group was elucidated by NOE of H-2/H-14 $\left[\delta_{\mathrm{H}} 3.90(1 \mathrm{H}, \mathrm{d}, J=12.9 \mathrm{~Hz})\right]$ and $\mathrm{H}-2 / \mathrm{H}-4\left[\delta_{\mathrm{H}} 1.88(1 \mathrm{H}, \mathrm{m})\right]$. Moreover, the $\alpha$-orientation of $\mathrm{H}-10$ in compound 1 was determined by NOE of $\mathrm{H}-13\left[\delta_{\mathrm{H}} 1.66(3 \mathrm{H}, \mathrm{s}, \mathrm{H}-13)\right] / \mathrm{H}-15$ $\left[\delta_{\mathrm{H}} 0.99(3 \mathrm{H}, \mathrm{s}, \mathrm{H}-15)\right]$. Thus, the structure of compound 1 was assigned as showed in Figure 2, and this compound was named $1 \beta, 2 \beta$-epoxy-10(H) $\alpha$-dauca-11(12)-ene-7 $\alpha, 14$-diol.

Figure 2. Structures of compounds 1 and 2.

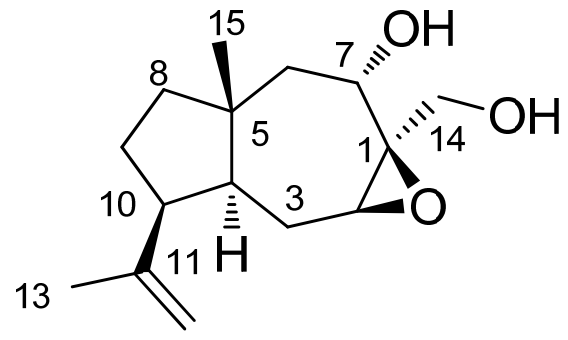

1

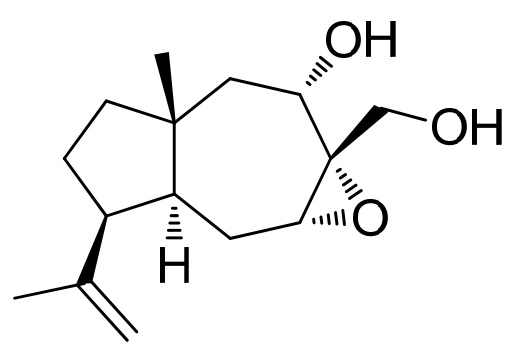

2

Compound $\mathbf{2}$ was obtained as a yellow oil and had the same molecular formula as $\mathbf{1}$ based on HR-ESI-MS $m / z \quad[\mathrm{M}+\mathrm{Na}]^{+} 275.1617$ (calcd for $\mathrm{C}_{15} \mathrm{H}_{24} \mathrm{O}_{3} \mathrm{Na}, 275.1623$ ), with four degrees of 
unsaturation. The IR spectrum also displayed the presence of hydroxyls $\left(3,419 \mathrm{~cm}^{-1}\right)$ and olefinic bond $\left(1,636 \mathrm{~cm}^{-1}\right)$ absorptions. The ${ }^{1} \mathrm{H}$ and ${ }^{13} \mathrm{C}$-NMR spectroscopic data of $\mathbf{2}$ was extremely similar to those of 1 except that C-2 $\left(\delta_{\mathrm{C}} 59.4\right)$ in compound 1 shifted down-field to $\delta_{\mathrm{C}} 61.8$ in $\mathbf{2}$ and $\mathrm{H}-2\left(\delta_{\mathrm{H}} 3.27\right)$ in $\mathbf{1}$ shifted up-field to $\delta_{\mathrm{H}} 3.15$ in 2, which hinted compound $\mathbf{2}$ was the isomer of $\mathbf{1}$ with different configuration of C-1 and C-2 (epoxy group). This was confirmed by the NOESY experiment. The relative configurations of the stereogenic centers (C-4, C-5, C-7, and C-10) of 2 were determined to be the same as those of compound 1 by NOE of H-15 $\left(\delta_{\mathrm{H}} 0.85\right) / \mathrm{H}-7\left(\delta_{\mathrm{H}} 4.29\right)$ and $\mathrm{H}-15 / \mathrm{H}-13\left(\delta_{\mathrm{H}} 1.73\right)$. The $a$-orientation of epoxy group was deduced by key NOE of H-2/H-12 $\left(\delta_{\mathrm{H}} 4.85\right)$ and $\mathrm{H}-7 / \mathrm{H}-14\left(\delta_{\mathrm{H}}\right.$ 4.07 and 3.30). The correlations in the HMBC and ${ }^{1} \mathrm{H}-{ }^{1} \mathrm{H}$ COSY spectrum (Figure 1) further confirmed the assignments of $\mathbf{2}$. Thus, the structure of compound $\mathbf{2}$ was assigned as showed in Figure 2, and was named $1 \alpha, 2 \alpha$-epoxy-10(H) $\alpha$-dauca-11(12)-ene-7,14-diol. Finally the anti-HIV-1 and inhibitory AChE activities of compounds $\mathbf{1}$ and $\mathbf{2}$ were evaluated. The two new compounds showed no activity against HIV-1 and AChE.

\section{Experimental}

\subsection{General}

Spectra were recorded on the following instruments: optical rotation, Jasco P-1020 polarimeter; UV, Shimadzu double-beam 210A spectrometer; IR, Tensor 27 spectrometer (KBr pellets); NMR; Bruker AV-400 or a DRX-500 spectrometer (TMS as an internal standard using $\mathrm{CDCl}_{3}$ as solvent); ESI-MS and HR-ESI-MS, API QSTAR Pulsar 1 spectrometer. Silica gel (200-300 mesh, Qingdao Marine Chemical Inc., Qingdao, China), RP-18 (40-70 $\mu$ m, Fuji Silysia Chemical Ltd., Aichi, Japan) and Sephadex LH-20 (Amersham Biosciences, Uppsala, Sweden) were used for column chromatography. Semipreparative HPLC was performed on an Agilent 1100 liquid chromatograph equipped with a Zorbax SB-C ${ }_{18}, 9.4 \mathrm{~mm} \times 25 \mathrm{~cm}$ column. Fractions were monitored by TLC and spots were visualized by heating after spraying with $5 \% \mathrm{H}_{2} \mathrm{SO}_{4}$ in ethanol.

\subsection{Plant Material}

The stems of Daphne aurantiaca Diels. were collected in Xianggelila Yunnan Province, People's Republic of China. A voucher specimen (CHRX0001), identified by Prof. H. Sun and Dr. L.L. Yue (Kunming Institute of Botany, Chinese Academy of Sciences), was deposited in Institute of Tropical Bioscience and Biotechnology, Chinese Academy of Tropical Agricultural Sciences.

\subsection{Extraction and the Isolation}

The dried and powdered stems of Daphne aurantiaca $(4.5 \mathrm{~kg}$ ) were extracted with $95 \% \mathrm{EtOH}(15 \mathrm{~L})$ under reflux three times. The extract was concentrated and suspended in water followed by successive partition with petroleum ether $(3 \times 4 \mathrm{~L})$ and EtOAc $(3 \times 4 \mathrm{~L})$. The EtOAc extract $(300 \mathrm{~g})$ was separated by silica gel column using a gradient solvent $\mathrm{CHCl}_{3} / \mathrm{MeOH}(9: 1-3: 1 \quad 10 \mathrm{~L})$ to afford fractions A-C. Fraction A (40 g) was separated by silica gel column using a gradient solvent petroleum ether/EtOAc (20:1-1:2 $8 \mathrm{~L})$ to afford fractions A1-A4. Fr. A2 (5g) was purified over Sephadex LH-20 column $\left(\mathrm{CHCl}_{3} / \mathrm{MeOH}\right.$ 1:1 $\left.3 \mathrm{~L}\right)$ to give two subfractions A2-1 and A2-2. Subfr.A2-1 
(2 g) was subjected to repeated RP-18 column $\left(\mathrm{MeOH} / \mathrm{H}_{2} \mathrm{O} 2: 12 \mathrm{~L}\right)$ to obtain the mixture two compounds 1 and 2. The mixture $(42.3 \mathrm{mg})$ was further separated by semi-preparative HPLC $\left(\mathrm{MeOH} / \mathrm{H}_{2} \mathrm{O} 45: 550.5 \mathrm{~L}\right)$ to yield $\mathbf{1}(11.7 \mathrm{mg})$ and $\mathbf{2}(8.5 \mathrm{mg})$.

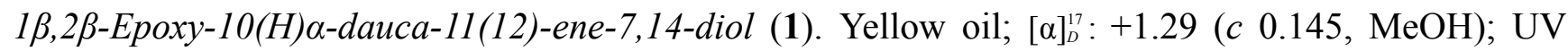
$(\mathrm{MeOH}) \lambda_{\max }(\log \varepsilon) 202$ (3.54), 229 (2.66); IR (KBr) $v_{\max }$ 3425, 2950, 2878, 2858, 1635, 1454, 1383, 1107, 1067, 1055, 1024, 889; ${ }^{1} \mathrm{H}$ and ${ }^{13} \mathrm{C}$-NMR see Table 1; ESI-MS positive $m / z[\mathrm{M}+\mathrm{Na}]^{+} 275(100)$; HR-ESI-MS $m / z[\mathrm{M}+\mathrm{Na}]^{+} 275.1628$ (calcd for $\mathrm{C}_{15} \mathrm{H}_{24} \mathrm{O}_{3} \mathrm{Na}, 275.1623$ ).

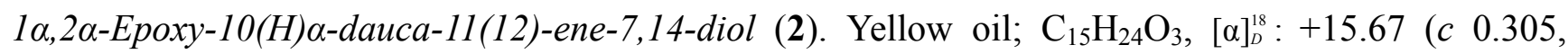
$\mathrm{MeOH}) ; \mathrm{UV}(\mathrm{MeOH}) \lambda_{\max }(\log \varepsilon) 202$ (3.57), 237 (2.47); IR (KBr) $v_{\max } 3419,2949,2930,2855,1636$, 1451, 1382, 1024, 972, 890; ${ }^{1} \mathrm{H}$ and ${ }^{13} \mathrm{C}-\mathrm{NMR}$ see Table 1; ESI-MS positive $\mathrm{m} / z$ [M+Na] $275(100)$; HR-ESI-MS $m / z[\mathrm{M}+\mathrm{Na}]^{+} 275.1617$ (calcd for $\mathrm{C}_{15} \mathrm{H}_{24} \mathrm{O}_{3} \mathrm{Na}, 275.1623$ ).

\subsection{Anti-HIV-1 Bioassay}

The anti-HIV activity was evaluated by the inhibition assay for the cytopathic effects of HIV-1 $\left(\mathrm{EC}_{50}\right)$ and cytotoxicity assay against $\mathrm{C} 8166$ cell line $\left(\mathrm{IC}_{50}\right)$ using MTT methods as described in the literature [8]. AZT (3'-azido-3'-deoxythymidine, Sigma-Aldrich 99\%, Seelze, Germany) was used as positive control. The concentration of the antiviral sample reducing HIV-1 replication by $50 \%\left(\mathrm{EC}_{50}\right)$ was determined from the dose response curve and calculated by Reed and Muench method [9].

\subsection{Bioassay of AChE Inhibitory Activity}

Acetylcholinesterase inhibitory activity was assayed by the spectrophotometric method developed by Ellman [10] with slightly modification. $S$-Acetylthiocholine iodide, 5,5'-dithio-bis-(2-nitrobenzoic) acid (DTNB, Ellman's reagent), acetylcholinesterase derived from human erythrocytes were purchased from Sigma Chemical (Perth, Australia). Compounds were dissolved in DMSO. The reaction mixture (totally $200 \mu \mathrm{L}$ ) containing phosphate buffer ( $\mathrm{pH} 8.0$ ), test compound (50 $\mu \mathrm{M}$ ), and acetyl cholinesterase $(0.02 \mathrm{U} / \mathrm{mL})$, was incubated for $20 \min \left(30^{\circ} \mathrm{C}\right)$. The reaction was initiated by the addition of $20 \mu \mathrm{L}$ of DTNB $(0.625 \mathrm{mM})$ and $20 \mu \mathrm{L}$ acetylthiocholine iodide $(0.625 \mathrm{mM})$ for AChE inhibitory activity assay. The hydrolysis of acetylthiocholine was monitored at $405 \mathrm{~nm}$ after $30 \mathrm{~min}$. Tacrine (Sigma-Aldrich 99\%) was used as positive control with final concentration of $0.333 \mu \mathrm{M}$, and DMSO was used as negative control with final concentration of $0.1 \%$. All the reactions were performed in triplicate. The percentage inhibition was calculated as follows: \% inhibition $=(E-S) / E \times 100(E$ is the activity of the enzyme without test compound and $\mathrm{S}$ is the activity of enzyme with test compounds).

\section{Conclusions}

The phytochemical investigation of Daphne aurantiaca led to the isolation of two new dacane sesquiterpenoids named $1 \beta, 2 \beta$-epoxy-10(H) $\alpha$-dauca-11(12)-ene-7 $\alpha, 14$-diol (1) and $1 \alpha, 2 \alpha$-epoxy$10(H) \alpha$-dauca-11(12)-ene-7 $\alpha, 14$-diol (2), which were isomers. The evaluation on anti-HIV-1 and inhibitory AChE activities of two new dacane sesquiterpenoids showed these two isolates exhibited no activity against HIV-1 and AChE. 


\section{Acknowledgments}

This work was financially supported by the National Nonprofit Institute Research Grant of CATAS (ITBB110301; 1630052012014) and the Natural Science Foundation of Hainan (211020). The authors thank the members of the analytical group of the State Key Laboratory of Phytochemistry and Plant Resources in West China, Kunming Institute of Botany, for the spectral measurements.

\section{References}

1. Kunming Institute of Botany, Chinese Academy of Sciences. Flora of Yunnan; Science Press: Kunming, China, 1997; p. 219.

2. $\quad$ Liang, S.; Shen, Y.H.; Feng, Y.; Tian, J.M.; Liu, X.H.; Xiong, Z.; Zhang, W.D. Terpenoids from Daphne aurantiaca and their potential anti-inflammatory activity. J. Nat. Prod. 2010, 73, 532-535.

3. Badawi, M.M.; Handa, S.S.; Kinghorn, A.D.; Cordell, G.A.; Farnsworth, N.R. Plant anticancer agents XXVII: Antileukemic and cytotoxic constituents of Dirca occidentalis (Thymelaeaceae). J. Pharm. Sci. 1983, 72, 1285-1287.

4. Carney, J.R.; Krenisky, J.M.; Williamson, R.T.; Luo, J.; Carlson, T.J.; Hsu, V.L.; Moswa, J.L. Maprouneacin, a new daphnane diterpenoid with potent antihyperglycemic activity from Maprounea africana. J. Nat. Prod. 1999, 62, 345-347.

5. He, W.; Cik, M.; Lesage, A.; van der Linden, I.; de Kimpe, N.; Appendino, G.; Bracke, J.; Mathenge, S.G.; Mudida, F.P.; Leysen, J.E.; et al. Kirkinine, a new daphnane orthoester with potent neurotrophic activity from Synaptolepis kirkii. J. Nat. Prod. 2000, 63, 1185-1187.

6. Huang, S.Z.; Zhang, X.J.; Li, X.Y.; Jiang, H.Z.; Ma, Q.Y.; Wang, P.C.; Liu, Y.Q.; Hu, J.M.; Zheng, Y.T.; Zhou, J.; et al. Phenols with anti-HIV activity from Daphne acutiloba. Planta Med. 2012, 78, 182-185.

7. Huang, S.Z.; Zhang, X.J.; Li, X.Y.; Kong, L.M.; Jiang, H.Z.; Ma, Q.Y.; Liu, Y.Q.; Hu, J.M.; Zheng, Y.T.; Li, Y.; et al. Daphnane-type diterpene esters with cytotoxic and anti-HIV-1 activities from Daphne acutiloba Rehd. Phytochemistry 2012, 75, 99-107.

8. Zhang, G.H.; Wang, Q.; Chen, J.J.; Zhang, X.M.; Tam, S.C.; Zheng, Y.T. The anti-HIV-1 effect of scutellarin. Biochem. Biophys. Res. Commun. 2005, 334, 812-816.

9. Reed, L.J.; Muench, H. A simple method for estimating fifty percent endpoints. Am. J. Epidemiol. 1938, 27, 493-497.

10. Ellman, G.L.; Courtney, K.D.; Andres, V.J.; Featherstone, R.M. A new and rapid colorimetric determination of acetylcholinesterase activity. Biochem. Pharmacol. 1961, 7, 88-95.

Sample Availability: Samples of the compounds are available from the authors.

(C) 2012 by the authors; licensee MDPI, Basel, Switzerland. This article is an open access article distributed under the terms and conditions of the Creative Commons Attribution license (http://creativecommons.org/licenses/by/3.0/). 